\title{
Roundtable on Environmental Information and Documentation
}

$\mathrm{O}_{\mathrm{R}}^{\mathrm{n}}$ 25 February 1993, the IUCN Library hosted a Roundtable on Environmental Information and Documentation in the greater-Geneva area. Organized in cooperation with the International Academy of the Environment, the meeting brought together librarians and information managers from 32 intergovernmental, nongovernmental, and Swiss, institutions - among them two members of the IUCN family: Intercooperation (Switzerland) and the World Organization of the Scout Movement.

During the lively discussion at the Roundtable it was decided to start work on a number of cooperative activities: creation of a Directory of Regional Information Sources, development of a Réseau d'alerte sur la littérature de la biodiversité en langue française, and inves- tigation of suitable thesauri for indexing environmental and sustainable-development literature. These activities will be undertaken by a number of volunteers who will report back to a second meeting of the Roundtable later this year.

These new developments appear destined to extend in useful ways the facilities and effectiveness of the greaterGeneva area as a leading centre of environmental, conservational, and allied, activity.

KEVIN GRose, Head Librarian
IUCN World Headquarters
Rue Mauverney 28
CH-I196 Gland
Switzerland.

Kevin Grose, Head Librarian Rue Mauverney 28 Switzerland.

\section{Immigration Policy: Learning from Neighbours}

$\mathrm{M}$ igration has become a dominant political issue both nationally and internationally in the 1990s. As migration pressures continue to rise, immigrant-receiving countries' search for control is becoming more and more urgent. Unemployment, overburdened social programmes, housing shortages, overpopulation, environmental degradation, political upheaval, and the quest for European unity, are among the factors that have led many nations to rethink their immigration policies. Despite limited steps in Europe, there is a conspicuous lack of cooperation and information exchange among nations on which immigration will inevitably have a significant economic, social, and political, impact.

A new comparative study, Immigration and Nationality Policies of Leading Migration Nations, published by the Center for Immigration Studies, examines past and current migration policies of eleven countries and efforts by the European Community to harmonize immigration policy. It is a compendium of individual country reports, edited by the undersigned, in which each country report includes detailed information on immigration law, immigrant numbers and categories, illegal immigration, enforcement, immigrant rights, and naturalization policy. It is available from the address below at $\$ 18$ post-paid.

This compilation identifies many of the common issues on which increasingly heated national migration debates are focused, and it points out disparities as well. Many European countries have come to recognize that migration presents them with a continental problem requiring a multilateral, European approach. Even before violent attacks against aliens began in Germany, most Western European countries were experiencing a backlash against large numbers of resident aliens - legal as well as illegal. While attempting to stem the migrant flow, Germany, France, Italy, Spain, and others, have also adopted policies to lessen social unrest by encouraging the assimilation of legal residents into the national culture. The United States, on the other hand, has ignored the role which immigration plays in social strife and moved towards ever-larger numbers of immigrants.

The compendium is the first part of an ongoing project of the Center for Immigration Studies. It includes reports on Argentina, Australia, Canada, France, Germany, Italy, Mexico, Spain, Sweden, the United Kingdom, and the United States - all of which are major immigrant-sending or -receiving countries. The Center plans to update these reports as needed, and to complete new ones on such nations as Belgium, Brazil, Israel, Japan, the Netherlands, the Philippines, and Switzerland.

ROSEMARY JENKS, Senior Analyst
Center for Immigration Studies
1815 H Street, NW
Suite 1010
Washington
DC 20006, USA.

ROSEMARy Jenks, Senior Analyst Center for Immigration Studies

Suite 1010

DC 20006, USA.

\section{World Environment Center Gold Medal for International Corporate Environmental Achievement}

$\mathrm{T}$ The 1993 WEC Gold Medal for International Corporate Environmental Achievement has been awarded to the Xerox Corporation for its proactive environmental policy which has progressively strengthened since the 1960 s. That policy goes beyond the baseline of compliance and includes ongoing and measurable waste-reduction goals. 'Design for the Environment', which addresses environmental concern throughout product life-cycles, an ambitious energy and resource-conservation programme, and a policy that encourages both in-house and customer recycling of copier cartridges and paper, are all part of Xerox Corporation's proactive management practices at locations world-wide. Early on, and made possible by technological advances, Xerox Corporation banned all PCB- and asbestos-containing components.
Xerox's Environmental Health and Safety Department was formed in 1980 to advance environmental programmes. Included are annual environmental audits of all manufacturing facilities world-wide to identify hazards and ensure compliance with the highest environmental standards established by the Corporation. Site Wastereduction and Recycling programmes complement Xerox Corporation's 'close the loop' materials purchasing practices. In 1985, Xerox Corporation initiated a voluntary clean-up of ground-water contamination on its properties world-wide.

The Corporation also plays a leading role in new technology application through innovations such as the elimination of ozone-depleting chlorofluorocarbons in packaging and service materials, the replacement of most 
solvents with aqueous cleaners, and dry-ice-based cleaning. Reusable part-shipping containers and the refurbishing and remanufacturing of returned parts are Xerox's world-wide practices. The Corporation was the first to introduce two-sided copiers and laser printers.

Xerox Corporation's 'Environmental Leadership Program' addresses all aspects of company operations with increased focus on environmental product-design and resource conservation. 'Cradle-to-grave' life-cycle design requirements have been adopted to minimize environmental impact and provide savings through parts' recovery, remanufacturing, and recycling.

Environmental education and training are keys to achieving Corporation policy objectives. Environmental information reaches shareholders, employees, customers, and the community at large. Xerox Corporation's Social Service Leave and Community Involvement Programs encourage employees to work on community projects, in- cluding environmental protection. 'Business Guide to Waste Reduction and Recycling', a comprehensive 'howto' manual on implementing waste reduction, was originally intended for in-house use but is now widely distributed.

In its commitment to continuous improvement for a better environment, Xerox Corporation has adopted the belief that "environmental health and safety concerns take priority over economic considerations', and that environmental responsibility is 'a race without a finish-line'. In the words of its Chairman and Chief Executive Officer, Paul A. Allaire, such an approach '... makes good business sense for Xerox Corporation'.

WORLd Environment CENTER
419 Park Avenue South, Suite 1800
New York
NY 10016, USA.

\section{The Healing Forest Conservancy}

$I^{n}$ 1989, the non-profit Healing Forest Conservancy was founded to promote the conservation of tropical forests and the welfare of tropical forest peoples, both of which are, today, threatened with extinction. It has been calculated that, every second of every day, a tropical forest the size of a football field is destroyed, eroding the biological diversity of life itself, and diminishing forests' ability to moderate climate and maintain ecosystem and ultimately ecocomplex - functions. Forest peoples thereby lose their homelands and Humankind loses generations of knowledge and the use of forest resources. A vicious cycle of poverty, destructive population and consumption practices, poor land-use, and inappropriate development policies, has doubled the rate of tropical deforestation in the past decade.

Yet tropical forests - habitat of almost half the plant and animal species on planet Earth - represent veritable laboratories of critical biological resources of Humankind - medicinal plants. The amount and value of this wealth of biological diversity is still uncalculated, even though as large a proportion as one-fourth of the prescription drugs on the market in the US today are plant-derived. It is conservatively estimated that, in 1989 alone, American consumers spent over US $\$ 8$ thousand millions on prescription drugs which contained active ingredients that are still extracted from higher plants.

Peoples who have traditionally lived in or near tropical forests represent libraries of information, accumulated over millennia, on the use of plants for medicinal purposes. The World Health Organization estimates that, today, $80 \%$ of the population of developing countries - about 4 thousand million people - depend on traditional medicine for their primary health-care. Likewise, traditional knowledge of plant use in the gene-rich developing world proves valuable to the gene-poor developed world when scientists focus this knowledge to lead their plant research. Of the 120 active compounds that are currently isolated from higher plants and used in Western medicine, $74 \%$ have the same therapeutic use as in traditional societies.

This knowledge is embedded in forest peoples' cultural systems which are as rich and diverse as their biological resources - and as threatened! Since 1900, due to outside encroachment and loss of habitat, extinction has been the fate of an average of one indigenous culture each year in the Amazon region alone. As the medicinal value of this biocultural diversity for present and future generations world-wide becomes more and more apparent, its conservation becomes more and more urgent.

In response to this lacuna in the capability of fulfilling human needs, the Healing Forest Conservancy was founded through a donation from Shaman Pharmaceuticals, Inc., to secure the long-term survival of the traditional knowledge of medicinal plants and the biological diversity of tropical forests. Shaman is a Northern California-based company focused on the discovery and development of novel pharmaceuticals derived from higher plants. The Conservancy will funnel part of the profits generated by the commercialization of plant-derived compounds to the people and countries where medicinal plant research and harvesting are conducted. The Healing Forest Conservancy responds to immediate needs of its counterpart enterprises as well, through development and support of projects that:

(a) promote sustainable development by local harvesting of natural products in forests which might otherwise be cut for timber or cleared for cattle-grazing;

(b) train local people as parataxonomists in methods for species collection, identification, and inventory, of local genetic resources;

(c) build and strengthen indigenous institutions through collegiate relationships;

(d) exchange and merge traditional and non-traditional scientific methods and processes;

(e) empower local people through education and communication between groups and the outside world;

(f) promote the health and welfare of indigenous cultures; and

(g) include sponsoring and administering the Richard Evans Schultes Award 'for outstanding contributions to the field of ethnobotany or to indigenous peoples' issues related to ethnobotany'**

Katy Moran, Executive Director The Healing Forest Conservancy 3521 S Street $N W$

Washington

DC 20007, USA

* See also the following item in this issue. The Conservancy is now accepting nominations for the 1994 Richard Evans Schultes Award. - Ed. 